
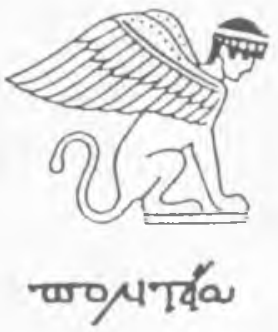

\section{МНОГОГРАННАЯ ГЛОБАЛИЗАЦИЯ}

Грани глобализации. Трудные вопросы современного развития. М.: Альпина Паблишер, 2003. - 592 с.

В последнее время феномен глобализации притягивает к себе все больше внимания социологов и историков, политологов и философов. Этому сложному явлению посвящена и новая коллективная монография, подготовленная Фондом Горбачева. Рассматривая различные грани глобализации, авторы не дают простых ответов на сложные вопросы. Уже в предисловии М.С.Горбачев подчеркивает, что необходимо различать глобализацию как объективное явление и политику неолиберального глобализма, то есть ту форму, которую приобрел этот объективный процесс в современном мире.

Книга состоит из трех частей: первая включает главы, посвященные концептуальному рассмотрению отдельных сторон процесса глобализации; вторая часть посвящена анализу важнейших проблем современности в контексте глобализации; в третьей части исследуется положение и перспективы России в глобализирующемся мире.

Авторы рецензируемого труда трактуют глобализацию как процесс становления единого мира - «целостного и по своим общим контурам, и по внутренней взаимосвязанности своих взаимопроникающих компонентов" (с. 193). Они отмечают, что само становление единого взаимозависимого мира, получившего наименование «глобального», стало реальностью конца XX - начала XXI века. Это объективное явление трансформирует самые различные сферы жизни мирового сообщества: экономику и финансы, технологии и товаропотоки, социальную и политическую жизнь, взаимодействие культур и цивилизаций. Более того, в рассматриваемой книге глобализация трактуется как процесс формирования глобального человеческого сообщества - «мегаобщества», по определению В.Б.Кувалдина. Действительно, в целом мир выходит на новый уровень взаимозависимости и взаимосвязанности. Становление мегаобщества связывается с перспективой постепенного создания глобальных сетей поверх существующих барьеров и границ. Тем самым перед человечеством открываются гигантские перспективы в таких сферах как развитие информатики, мировые коммуникации, транснациональные финансовые институты, взаимообогащение культур, противодействие новым вызовам и угрозам.

Вместе с тем, как отмечают авторы, глобализация вовсе не означает гомогенизации современного мира. Она выявляет и углубляет те противоречия и разрывы, которые существуют между государствами и народами. В.Б.Кувалдин вполне обоснованно утверждает: «Одной 
из важнейших причин большой конфликтности глобализационных процессов являются фундаментальные различия в уровне социальноэкономического и политического развития человеческих сообшеств, в образе жизни, в отношении к основным проблемам бытия, в системах ценностей. Сегодня они настолько велики, что можно сказать, что человечество живет в разных измерениях и мирах; частично они совпадают, частично существуют параллельно, частично даже не соприкасаются» (с. 43). Но при этом неизбежно возникает вопрос: можно ли в этой ситуации говорить о формировании мегаобшества? Ведь нынешняя практика глобализма еще более углубляет существующие разрывы между этими параллельными мирами. Представляется, что стоило усилить нотки оправданного скептицизма и пессимизма, говоря о современных глобализационных процессах. Конечно, отрицать саму глобализацию бессмысленно, но трансформировать практику неолиберального глобализма, думается, возможно.

Это положение раскрываются в других главах. Академики О.Т.Богомолов и А.Д.Некипелов трактуют глобализацию как особую стадию интернационализации производства. Она связана с новым качеством взаимозависимости экономик различных стран, с экспансией транснациональных корпораций, с возрастанием роли международньх экономических институтов. При этом подчеркивается, что экономическая глобализация не обеспечила устойчивого, динамичного роста мирового хозяйства и не решила задачу преодоления опасных разрывов в уровнях экономического развития разных стран. Авторы рассматривают не только чисто экономические вопросы, но и социальные аспекты, что способствует углублению анализа последствий глобализации. Ее воздействие на социально-экономическое развитие весьма противоречиво. Возрастает (или в лучшем случае сохраняется) разрыв между бедным «Югом» и богатым «Севером», хотя абсолютные темпы развития увеличились в обеих группах государств. В целом возрастающий разрыв между развивающимися странами и высокоразвитым миром, умноженный на раздражение и недовольство в результате демонстрации достижений общества потребления средствами массовой информации, порождает мощное социальное напряжение. Вместе с тем произошло расслоение «Юга» на относительно благополучные страны, втянутые в процессы глобализации, и «неудачников», остающихся на обочине мирового прогресса. Накопленный опыт убедительно доказывает, что экономическая система, ориентированная только на рынок при отсутствии других регулирующих механизмов. не может обеспечить гармоничное развитие в глобалыном масштабе. Поэтому-то столь актуальной становится проблема создания нового международного экономического порядка, чтобы избежать опасного нарастания выявившихся противоречий и конфликтов. Как отмечают авторы, негативные стороны глобализации заставляют по-новому посмотреть на господствующие в настоящее время эколомические теории и основанные на них политические концепции. 
Эту тему подхватывает и развивает В.М.Коллонтай, обращаясь к эволюции западных концепций экономической глобализации. Автор показывает нарастание критики неолиберальной глобализации, ее теории и практики. Происходит переосмысление роли рынка. «Рынок предстает не как самодовлеюший фактор, способный решить все проблемы и в корне преобразовать общество, а как составная часть общественного развития, как один из его механизмов, уходящий своими корнями во всю совокупность общественных отношений и зависящий в своем развитии от социально-политической сферы, от исторического и культурного наследия общества» (с. 157-158). Этот важный вывод побуждает по-новому взглянуть на судьбы российских реформ.

Государство выступает как основной инструмент регулирования рынка, определения общего контекста его самоорганизации. В действительности, справедливо подчеркивает В.М.Коллонтай, проблема заключается не в противопоставлении государства и рынка, а в выявлении наиболее действенных и полезных форм их взаимодействия и сопряжения в условиях глобализации. Конечно, речь идет о современном демократическом и правовом государстве. В целом, анализ социально-экономических аспектов глобализации убедительно выявляет недостатки и просчеты политики неолиберального глобализма, бесперспективность попыток навязать эту модель всему мировому сообществу.

Переосмысление позитивных и негативных аспектов глобализации побуждает искать новые подходы к проблеме управляемости как возможности воздействовать на происходящие процессы. Развертывается борьба за отстаивание и укрепление демократических основ общества, за трансформацию национальных демократических институтов и их использование для воздействия на механизм принятия мирохозяйственньх решений.

Проблема политической глобализации стала предметом специального рассмотрения М.В.Ильина. Он определяет ее как постепенное укрепление взаимодействия между нациями, цивилизациями и этнокультурами, ведущее к обретению взаимосвязанности и образованию структур глобальной управляемости, которые интегрируют прежде разобщенные фрагменты мироустройства (с. 195). Автор анализирует сложный процесс модернизации, его противоречивое влияние на перспективы перехода к управляемому и устойчивому развитию. Он подвергает критике иллюзии относительно возможности искусственного форсирования модернизации на неподготовленной почве путем следования рекомендациям Всемирного банка и внедрения опыта американской демократии. Констатируя качественное усложнение политики и структур политической организации к концу XX - началу XXI века, М.В.Ильин показывает, что в условиях глобализации создаются определенные предпосылки для появления альтернативных институтов демократического участия в управлении, которые могут стать зародышами новых форм контроля над развитием и возраста- 
ния управляемости процессами глобализации. При этом появляется возможность и необходимость дискуссий относительно широкого комплекса институциональных изменений в политической сфере, способных способствовать формированию демократического миропорядка и перехода к устойчивому развитию.

Несомненным достоинством рецензируемого труда является широкий подход к глобализации, ее рассмотрение в контексте глобальных проблем современности. На первое место при этом выдвигается глобальный экологический вызов, анализ которого предлагают В.И.Данилов-Данильян и К.С.Лосев. Они подчеркивают, что единственный шанс для человечества предотвратить биосферную катастрофу - это нормализовать антропогенное воздействие на окружающую среду, снизить его до уровня, определяемого хозяйственной емкостью биосферы. Российские исследователи предлагают не только прекратить самоубийственное наступление на природу, но отступить, создавая возможности для необходимого воздействия природных сил. Развитие человеческой цивилизации должно происходить в пределах хозяйственной емкости биосферы, все цивилизационные процессы должны быть приведены в соответствие с законами ее устойчивости. «В основу, - отмечают авторы, - должны быть положены координация, кооперация, взаимодополняемость, коэволюция стран и народов, диалог культур и конфессий, партнерство, взаимоуважение» (c. 274). Все эти замечательные рекомендации, естественно, побуждают солидаризироваться с ними. Однако возникает вопрос: кто и как будет их реализовывать? Где найти необходимые инструменты и средства для кардинального пересмотра парадигмы экономического и технологического развития?

Несомненный интерес вызывают главы, посвященные мировому населению (Н.М.Римашевская) и человеку в условиях глобализации (Г.Г.Дилигенский). Развивая положения предшествующей главы об экологии, Н.М.Римашевская также подчеркивает необходимость смены цивилизационной парадигмы, изменения самих моделей развития обшества. Высокие темпы роста населения стран «третьего мира» ведут к дальнейшему ухудшению экологической обстановки и препятствуют переходу к устойчивому развитию. К концу ХХ века численность населения планеты превысила 6 млрд. человек. При этом на развитые страны приходится менее 20\% всех жителей Земли; соотношение населения развитых и развивающихся страи все больше смещается в сторону последних. Демографическая революция по времени совпала с интенсификацией воздействия всех иных факторов глобализации. Авторы убедительно доказывают, что ее наиболее очевидным социальным последствием является углубление разрыва в социальноэкономическом положении массовых слоев населения развитых и развиватощихся или экономически отсталых стран. По оценкам ООН, в начале 90-х годов XX века на долю пятой части мирового населения, живущего в странах с наибольшим доходом, приходилось 86\% миро- 
вого ВВП, на долю пятой части, живущей в беднейших странах - всего $1 \%$, а на долю остальных $60 \%$ человечества - 13\% (с. 305). Более одного миллиарда людей лишены возможностей удовлетворять свои самые элементарные потребности. Глобализация закрепляет (а в некоторых случаях и увеличивает) бедность, насилие, отчужденность, она разрушает традиционный образ жизни ряда народов, зачастую навязывая взамен худшие аспекты вестернизации.

В условиях глобализации, как утверждает Г.Г.Дилигенский (ныне покойный), происходит одновременное усиление разнонаправленных социально-культурных тенденций: с одной стороны, возрастание свободы индивидуального выбора, с другой, распространение стандартов и норм западного общества потребления. В глобализации заключены различные, в том числе и противоположные, парадигмы социокультурного развития. При этом он соглашается с исследователями, констатируюшими растущее несовпадение процессов модернизации и вестернизации, сохранение культурного многообразия в современном мире. По мнению Г.Дилигенского, было бы неверно видеть главную причину вестернизации в агрессивной культурной экспансии Запада, опирающейся на его экономическую и технологическую мощь. Во многом вестернизация вызвана несоответствием ряда традиционных культур условиям современной экономической и социальной жизни, особенно быстро изменяющимся в условиях глобализации. Вынужденное заимствование западных образцов способно порождать острые конфликты во внутреннем мире личности, сохраняюшей архетипы традишионной культуры. Решение конфликта может достигаться на основе культурного синтеза, предполагающего интеграцию традиционных ценностей, трансформированных в соответствии с современными требованиями. Нарастание культурного и социально-психологического многообразия, вызванное глобализацией, является отнюдь не гармоничным процессом.

Большое внимание в рассматриваемой книге уделяется социокультурным аспектам глобализации. Выступая результатом и закономерным продолжением исторического развития, она вместе с тем вступает в глубокое противоречие с цивилизационными основами и всей системой ценностей современного мироустройства. При этом авторы, и в частности В.И.Толстых, подчеркивают, что выход из этого кризиса не может быть найден на путях навязывания всему миру системы западных ценностей, идеалов потребительского общества и принудительной вестернизации. Еще недавно вестернизация представлялась несомненным благом и отождествлялась с модернизацией. Одпако ныне вестернизация все еще воспринимается скорее как угроза цивилизационному разнообразию человечества. В противовес идее всемирного господства западной либеральной демократии и форсированной вестернизации В.И.Толстых выдвигает проект гуманистического глобализма, ориентированный на формирование многополюсного и многоликого сообшества стран, народов и культур, объе- 
диняющихся на основе гуманистических ценностей как современного западного, так и традиционного общества. «Проект базируется на идее диалога культур и цивилизаций, альтернативной идее якобы неизбежного столкновения между ними» (с. 417). При этом диалог призван выполнить функцию ценностноғо обеспечения иорм и форм нового миропорядка. Трудности на пути реализации данного проекта очевидны. Тем не менее, формирование «мегаобщества» настоятельно требует сопряжения и соразвития различных цивилизаций, синтеза их систем ценностей. Фактически другого реального пути нет. На все рассуждения оппонентов о необходимости возродить и усилить цивилизаторскую миссию западного мира уже дал убедительный ответ С. Хантингтон: «В возникающем мире этнических конфликтов и цивилизационных столкновений западная вера в универсальность западной культуры страдает тремя недугами: она ошибочна; она аморальна; она опасна». («Pro et contra», 1997, весна, с. 145).

Несомненным достоинством книги является то большое внимание. которое уделено позиционированию России в процессе глобализации (авторы этой части: В.Медведев, Ю.Красин, А.Галкин, А.Арбатов, А.Пикаев). Они рассматривают «самоопределение России» в политической, социальной, экономической и международной сфере. «С точки зрения национальных интересов России и ее эффективной роли в развитии мирового сообщества, - утверждают авторы, - оптимальный вариант политического самоопределения России - сильная демократия, которая положит конец самовластию и утвердит наделенную достаточными полномочиями исполнительную власть, действующую под контролем парламента и организаций гражданского общества. Речь должна идти не об отрицании получивших глобальное распространение принципов и ценностей демократии, а об их использовании с учетом исторических и социокультурных особенностей» (с. 464). Умеренная авторитарная власть, подчеркивается в труде, не решит вопрос о политическом самоопределении России. Скорее это точка бифуркации, от которой развитие может идти и к сильной демократии, и к жесткому авторитаризму.

Что касается социальной ориентации российского общества, то оно испробовало патерналистско-этатистскую и либерально-индивидуалистическую систему ценностей. При этом и Та, и другая выступали в России в своих наиболее последовательных, крайних модификациях, наглядно проявив все свои минусы. В результате наиболее предпочтительным выступает социально ориентированный и регулируемый вариант рыночной экономики, требующий глубоких реформ структурного характера для ухода от примитивного капитализма и раннего индустриализма.

Перед Россией стоит чрезвычайно сложная задача формирования собственного варианта экономики современного индустриальноинформашионного типа, интегрированной в мировое хозяйство. Для этого необходимо найти разумное сочетание постиндустриализма с 
национальными особенностями. Следует отметить, что в рецензируемом труде содержатся очень взвешенные оценки: нашей стране не предлагается копировать чужой опыт и идти по пути догоняюшего развития, вместе с тем не преувеличиваются особенности России и не отрицается необходимость ее включения в международные экономические механизмы. Что касается места России в современном мировом сообшестве, то авторы обоснованно подчеркивают: «Исторический опыт и нынешняя ситуация в мире убеждают, что для России важнее всего добиваться равновесности западного и восточного направлений, сбалансированности внешней политики как одного из устоев самостоятельности страны» (с. 503). При этом для нашей страны особенно нежелательно участвовать в комбинациях, противопоставляющих процветающий «золотой миллиард» громадной массе бедняков планеты. Отсюда и курс на неучастие в военно-политических союзах за рамками ближнего зарубежья, что, конечно, не исключает вхождение в коалиции ad hoc, соответствующие интересам России.

Авторы делают оптимистический вывод, что при умеренной авторитарной власти и осуществлении прорыва к социально ориентированной постиндустриальной экономике Россия сможет утвердить свое место одной из великих держав в мировом сообществе.

Рассматривая более подробно проблемы новой структуры международной безопасности, А.Арбатов и А.Пикаев подчеркивают, что выбор России может оказать ключевое влияние на формирование конфигурации мировой политики. Теоретически наша страна может осушествлять два альтернативных курса в международных делах: развитие отношений сотрудничества с развитыми странами Запада и участие в создании Северного кольца государств во главе с СIIA; ориентация на российско-китайский альянс и формирование аморфной антиамериканской коалиции государств «третьего мира» - большого Юга.

На современном этапе развития Москва сделала долгосрочный выбор в пользу Запада. Однако реализация этого выбора сталкивается с существенными трудностями. В их основе - стремление Запада отвести России роль подчиненного младшего партнера, не имеющего права на отстаивание собственных интересов. Прежде всего, это попытки США играть роль единственной глобальной сверхдержавы, проводить унилатералистскую политику в международных делах. Следует прибавить неготовность Запада способствовать модернизации высокотехнологических отраслей российской экономики, а также пойти на серьезную кооперацию в сфере военно-промышленного комплекса. К тому же в ходе переговоров о вступлении России в ВТО Запад выдвигает требования, неприемлемые для нашей страны; их удовлетворение способно серьезно осложнить развитие российской экономики. Все это вызывает настороженность и недовольство части российского обшественного мнения, которая выступает за переориентацию внешнеполитического курса Кремля. 
В целом российский читатель получил оригинальный научный труд, анализирующий различные аспекты столь сложного и противоречивого явления как глобализация, ее влияние на самые различные стороны эволюции современного международного сообшества.

В связи с этим возникает принципиальный вопрос, на который рецензируемый труд, к сожалению, ответа не дает или дает различаюшиеся ответы. Какие же процессы получили преобладание в ходе развития глобализации: формирование некоей новой взаимосвязанной обшности во всемирном масштабе (складывание "мегаобщества") или образование новых разрывов и фрагментация современного человечества на отдельные миры, существующие параллельно, а порой и противостоящие друг другу.

Рецензируемый коллективный труд вносит весомую лепту в изучение процессов глобализации, предлагает свое решение ряда научных проблем и заставляет задуматься над рядом новых вопросов. 